\title{
School Library as the Active Learning Center of the School
}

\author{
Antonija Lujanac \\ alujanac@gmail.com \\ Osnovna škola Dobriše Cesarića, Zagreb, Croatia
}

Keywords: active learning methods, outdoor classes, movement learning programs

\begin{abstract}
The fact is that many children, especially teenagers, suffer from mental and emotional stress and problems with their learning skills. Many of them are at risk of cardiovascular and locomotor system diseases because of the sedentary life-style. Most health experts agree that kids live sedentary if they do not exercise at least 30 minutes three times a week, have a lessons that requires little physical activity and sit most of the time. Physically active kids feel better what is prerequisite for successful learning but it is very often that pupils at school sit and learn using tablets, books, smartphones and computers. The needs of today pupils means active learning but also an active way of living. School library is one of the most appropriate location in the school to connect movement, creativity and learning.
\end{abstract}

\section{Introduction}

Active learning as a concept was described by English scholar R.W.Revans in the early 1970s. Different authors defined active learning, but it was always known as ,, a pedagogical strategy to engage students in their own learning“ (Bonwell and Eison, 1996). Starting in the 1970s, educator and reading specialist Paul E. Dennison began to explain learning as incremental changes in attention behavior and function. He anticipated our modern understanding of the brain by demonstrating how specific movements for eye-teaming, hand-eye coordination, and whole-body awareness brought swift improvements in reading, writing, understanding, and comprehension in students of all ages. The result was very original technique known as Brain Gym. Although we as the teachers know that active learning strategies help pupils to stay involved in their learning process, most of the classes in Croatia are still based on passive learning, where the teacher is at the center and pupils only listen or take notes. At this moment Croatian government and Ministry of the Education and Science start the implementation of the school curricular reform called School for Life.

\section{Active Learning: The Most Appropriate Learning Method}

Most of the educators agree that learning is a cognitive process of acquiring knowledge and information through experiences (Sgambi et al., 2019). Our students have changed radically. They are no longer the people our educational system was designed to teach. Some authors call them digital natives because their brain learns on a different way and for them is very important to be connected to social media (Prensky, 2001). On the other hand, some authors recommend that teachers have to meet their students better because digital native students show significant age related differences. This generation is not a homogeneous group (Jones et al., 2010). But we could all agree that kids and teenagers spend too much

International Association of School Librarianship

https://iasl-online.org 
time online. Young people and kids today have problems with posture, type 2 diabetes, high blood pressure, high cholesterol, teasing, low self-esteem, bullying and depression.

We can also notice that pupils and teenagers have difficulties with some basic skills like reading, writing and math. One study confirms that learning to read causes demonstrable changes in brain structure because the acquisition of literacy results from an effortful learning process that leads to functional changes in several cortical regions. "We explored whether learning to read also leads to anatomical changes within the left intrahemispheric white matter pathways that interconnect these regions" (Carreiras et al., 2009). Our mind and body are connected and learning process is more effective if we are active. This is why active learning is so important in schools and why physical coordination activities in the classroom can be used to organize the brain to develop skills like reading, writing and calculating.

Active learning activities are healthy and fun. They make learning process more effective and the learning environment suitable for pupils. An excellent teacher wants to put the pupils at the center of the learning process and help them to become more engaged, to develop higher levels of thinking and to build up good social skills. Social interaction is the most complex and fundamental of human behaviours. However, active learning methods have not yet made it to everyone who works with children. Because of that, it is very helpful to find online and for free practical recommendations by other teachers.

\section{School Library: The Most Appropriate Location for Active Learning}

If you have library in your school, it is great location for movement, playing and other active learning activities because they support basic skills like reading, writing, critical thinking and social skills. Today we can find a lot of similar but original concepts of active learning. Thanks to Erasmus+ program there are many high-quality projects in the European Union. One of them is the eTwinning project $\breve{S} k o l a u$ pokretu. The school library from Osnovna škola Dobriše Cesarića started this project thanks to Erasmus + project Arts talk about us and the experiences from school Mutala Koulu (Joensuu, Finland) and the program Fit4Kid (Slovenia).

The school library start to organize many activities to encourage the pupils and the teachers to be outside and move more in classroom. For example, the school librarian coordinate the projects of the urban gardening and volunteering (Oaza for Kids, Green fingers) but also playing with gymnastic props outside and in the school library. These activities encourage personal development and motivation of the students because they can use various sources of knowledge and to learn active in the group. School librarian helps the teachers to designe special brain gym games and connect the movement with some lessons. For example, how to learn the periodic system of elements thanks to the movement? Pupils search for information using books, internet and videos about chemistry and then on the balance beam form the individual groups of elements without going down. This game develops research skills, strategies, identifies similarities/differences, teamwork and balance. It is also very fun and it is the great 30 minutes of active learning lessons. Active learning is very effective learning method according to the Kolb's theory of learning styles and experimental learning cycle.

Reading requires the same cooperation between the two brain hemispheres. Balancing, skipping, jumping rope, dribbling and activities crossing the mid line are all very helpful strategies in treating reading difficulties. This kind of activities develops connections in the brain which may be used for reading fluency and comprehension, but it is also very important for cardiovascular health and body posture. Balancing on a balance beam activates the vestibular system, one of the entryways to the brain. There is evidence which suggests that learning is improved when this system is activated. Spinning in the direction of the dominant hand develops memory. Dribbling each hand individually, maintaining control of the ball

International Association of School Librarianship

https://iasl-online.org 
while standing still, also improves reading skills. Children dancing is the perfect activity to improve memory and support learning. Movement and learning are related, and dance in school is the ideal activity for learning. Dance combines music with a steady beat and coordination skills. Using art in math significantly improves retention of key concepts and vocabulary. Teaching children reading and math is more effective when teachers use core teaching strategies which apply brain science to support learning.

\section{Conclusion}

School librarians are experts who can promote active learning. Local community could financially support such programs because benefits of such activities are apparent. It is very important to know how the kids feel in school library. Do they feel safe, welcome and free? Does the interior in the library encourage movement? The brain learns best when it feels good. School library is perfect location to become a brain-friendly place where pupils can learn more easily. Active learning methods can improve and enhance learning. There are many ways to integrate active learning into the curriculum. Drawing, singing, acting and dancing should be a part of the learning process. It is very important fact that such activities must be placed into context to have meaning. Not only they support learning, but they are also critically important for children who live sedentary way of life.

\section{REFERENCES}

Bonwell, C.C.; Eison, J.A. Active learning: creating excitement in the classroom. ERIC [Online] 1991. https://files.eric.ed.gov/fulltext/ED336049.pdf (accessed July 8, 2019).

Carreiras, M.; Seghier, M.L.; Baquero, S.; Estevez, A.; Lozano, A.; Devlin, J.T.; Price, C. J. An anatomical signature for literacy. Nature 2009, 461, 983-986.

Castro-Caldas, A.; Petersson, K. M.; Reis, A.; Stone-Elander, S.; Ingvar, M. The illiterate brain: learning to read and write during childhood influences the functional organization of the adult brain. Brain 1998, 121, 1053-1063.

Jones, C.; Ramanau, R.; Cross, S.; Healing, G. Net generation or Digital Natives: Is there a distinct new generation entering university? Computers \& Education [Online] 2010, 54(3), 722-732. http://dx.doi.org/doi:10.1016/j.c (accessed June 12, 2019).

Jones, P. H. Brain exercises and physical coordination are benefits of physical education. Teacher Support Force Web site. http://www.teacher-support-force.com/brainexercises.html (accessed June 20, 2019).

Peko, A.; Varga, R. Active learning in classrooms. Život i škola 2014, 60 (31), 59-75.

Prensky, M. Digital natives, digital immigrants. MCB University Press. [Online] 2001, 9 (5). https:/www.marcprensky.com/writing/Prensky\%20\%20Digital\%20Natives,\%20Digital\%20Immi grants\%20-\%20Part1.pdf (accessed July 8, 2019).

Sgambi, L.; Kubiak, L.; Basso, N.; Garavaglia, E. Active learning for the promotion of students' creativity and critical thinking: an experience in structural courses for architecture. Archnet-IJAR [Online]. 2019. https://doi.org/10.1108/ARCH-11-2018-0018 (accessed June 12, 2019).

International Association of School Librarianship

https://iasl-online.org 
Smith-Collins, A.; Fiorentini, C.; Kessler, E.; Boyd, H.; Roberts, F.; Skuse, D. H. Specific neural correlates of successful learning and adaptation during social exchanges. Social Cognitive and Affective Neuroscience. [Online] 2013, 8 (8), 887-896. https://doi.org/10.1093/scan/nss079 (accessed July 12, 2019).

\section{Biographical Notes}

Antonija Lujanac studied pedagogy and information science at Faculty of Humanities and Social Sciences, University of Zagreb, Croatia. She works at elementary school Osnovna škola Dobriše Cesarića in Zagreb as school librarian and international project coordinator. She is involved with Erasmus+ projects in international pedagogical researches and good practice exchange. 